\title{
Dietary iron chelate for sows and effects on iron supplementation in piglets
}

\author{
CARINE A. BARROS ${ }^{1}$, LEONARDO A.F. PASCOAL ${ }^{1,2}$, PEDRO H. WATANABE ${ }^{3}$, \\ TEREZINHA D.D. MARTINS ${ }^{2}$, TIAGO S. ANDRADE ${ }^{3}$ and JOSÉ E.S. RIBEIRO ${ }^{2}$ \\ ${ }^{1}$ Centro de Ciências Agrárias, Universidade Federal da Paraíba, Campus II, Rodovia PB-079, 58397-000 Areia, PB, Brazil \\ ${ }^{2}$ Departamento de Ciência Animal, Centro de Ciências Humanas, Sociais e Agrárias, Universidade Federal da \\ Paraíba, Campus III, Rua João Pessoa, s/n, Cidade Universitária, 58220-000 Bananeiras, PB, Brazil \\ ${ }^{3}$ Departamento de Zootecnia, Centro de Ciências Agrárias, Universidade Federal do Ceará, \\ Campus do Pici, Av. Mister Hull, 2977, 60440-900 Fortaleza, CE, Brazil
}

Manuscript received on May 25, 2018; accepted for publication on October 26, 2018

\begin{abstract}
How to cite: BARROS CA, PASCOAL LAF, WATANABE PH, MARTINS TDD, ANDRADE TS AND RIBEIRO JES. 2019. Dietary iron chelate for sows and effects on iron supplementation in piglets. An Acad Bras Cienc 91: e20180509. DOI 10.1590/0001-3765201920180509.
\end{abstract}

\begin{abstract}
In order to evaluate iron chelate in diets for sows during gestation and lactation and its effects on iron supplementation for piglets, a total of 50 pregnant sows in the third parity order were distributed according to a randomized block design with two treatments: diet without iron chelate supplementation $(n=20)$; diet supplemented with $0.15 \%$ of iron chelate $(n=30)$. The litters of sows were distributed into five different treatments: sows without iron chelate supplementation and piglets receiving intramuscular iron-dextran; sows without iron chelate supplementation and piglets receiving oral iron supplementation; sows supplemented with iron chelate and piglets receiving intramuscular iron-dextran; sows supplemented with iron chelate and piglets receiving oral iron supplementation; sows supplemented with iron chelate and piglets without iron supplementation. No influence of dietary supplementation of iron chelate was verified on the productive parameters of the sows. For the piglets, iron-dextran supplementation promoted higher weaning weight in comparison to non-supplemented piglets, although not differing to those received oral iron supplementation. Thus, iron chelate supplementation did not improve the productive parameters of sows, but it increased iron excretion in the feces, thus requiring iron supplementation for the piglets after birth.
\end{abstract}

Key words: anemia, iron-dextran, iron-chelate, organic mineral.

\section{INTRODUCTION}

Iron deficiency anemia in suckling piglets is caused by a low supply of this mineral below the daily requirements; it mainly affects newborn animals due to low iron transfer from the sow to the

Correspondence to: Leonardo Augusto Fonseca Pascoal E-mail: leonardo@cchsa.ufpb.br ORCid: https://orcid.org/0000-0002-7225-5251 progeny through the placenta and also due to the low mineral content in milk (Liu et al. 2014).

To avoid problems arising from anemia, farms have commonly adopted an application of a $200 \mathrm{mg}$ intramuscular iron-dextran injection up to the third day of the piglet's life (Jolliff and Mahan 2011). Although good results in anemia prevention have been observed, this compound has been associated with cases of toxicity, injuries and muscular diseases 
in piglets, thus requiring a search for alternative methods, such as oral supplementation of non-toxic iron compounds (Peters and Mahan 2008a).

In turn, the diet of sows is usually supplemented with inorganic minerals which have limitations regarding their availability, and may not meet the mineral requirements. In this perspective, minerals ionically bound to organic molecules such as amino acids have shown better absorption and lower risk of interaction with other minerals in comparison to inorganic minerals, thus allowing better utilization by the sows, and consequently by the piglets (Wang et al. 2013).

Given the above, the objective of this study was to evaluate the effects of dietary iron chelate supplementation for sows during gestation and lactation on their reproduction performance, mineral concentration in colostrum and milk, and its implication on the performance of piglets receiving intramuscular and oral iron supplementation during farrowing phase.

\section{MATERIALS AND METHODS}

The experiment was carried out on a commercial farm located in Maranguape, Ceará State, Brazil, over a 51-day period. The experimental protocols used in this study were approved by the Ethics Committee on the Use of Animals (CEUA, $\mathrm{n}^{\circ}$ 13/2016) of the Universidade Federal da Paraíba.

A total of 50 gestation sows (Topigs Norsvin ${ }^{\circledR}$ ) in the third parity order were used with an average weight of $223.90 \pm 24.87 \mathrm{~kg}$. The sows (Topigs Norsvin ${ }^{\circledR}$ ) with 84 days of gestation were distributed into two treatments according to a randomized block design based on their initial weight. The treatments were: $\mathrm{W} / \mathrm{oFe}$ - Diet without iron chelate supplementation $(\mathrm{n}=20) ; \mathrm{FeC}$ - Diet supplemented with $0.15 \%$ iron chelate source $(n=30)$.

The diets were formulated to meet the nutritional requirements of sows during the studied phases according to Topigs Norsvin manual (Table
I). At gestation, the sows were fed $3.0 \mathrm{~kg}$ /day of pelleted feed; after birth a gradual feeding program was performed to stimulate feed intake, starting with $2.0 \mathrm{~kg}$ on day 1 postpartum and reaching 7.0 $\mathrm{kg}$ on day 8 postpartum, remaining constant until weaning.

Then animals were taken to the farrowing stalls at 110 days of gestation where they received the pre-lactation diet. The number of piglets born alive, stillborn and mummified at birth was recorded. The leftovers were collected during all of the lactation phase and feed conversion per $\mathrm{kg}$ of weaned piglets and percentage of weaned piglets were calculated.

Samples of colostrum and milk were collected at $1,7,14$ and 21 days postpartum and stored in freezer at $-5^{\circ} \mathrm{C}$ for further analysis. The iron was measured in duplicate according to the colorimetric absorbance procedure using the Labtest Ferroserum $\mathrm{Kit}^{\circledR}$.

Fecal samples of sows at 100 days of gestation were collected for 3 consecutive days to determine the concentration of iron, zinc and copper in feces. After collection, samples were homogenized per animal and frozen. They were subsequently predried at $55^{\circ} \mathrm{C}$ for 72 hours in a forced ventilation oven. The samples $(250 \mathrm{mg})$ were digested in 7 $\mathrm{mL}$ of a nitro-perchloric solution (1:2.5), diluted with distilled water and analyzed by an iCE 3500 atomic absorption spectrometer with atomizer flame (Thermo scientific, Cambridge, England) to determine the iron, zinc and copper concentrations. The absorbances were measured at $248.3 \mathrm{~nm}$, $213.9 \mathrm{~nm}$ and $324.8 \mathrm{~nm}$ wavelengths for iron, zinc and copper, respectively. Hollow cathode lamps (Photron, Victoria, Australia) containing the metals to be analyzed were used as the primary source of radiation and the background correction was done with a deuterium lamp coupled to the equipment. Standard curves were prepared with specific standards for each metal (Specsol, São Paulo, Brazil) and the data were processed using the 
TABLE I

Composition, nutritional and energy content of experimental diets at gestation, pre-lactation and lactation phases of sows supplemented or not with iron chelate.

\begin{tabular}{|c|c|c|c|c|c|c|}
\hline \multirow{3}{*}{ Ingredients $^{1}$} & \multicolumn{6}{|c|}{ Experimental diets (\%) } \\
\hline & \multicolumn{2}{|c|}{ Gestation } & \multicolumn{2}{|c|}{ Pre-lactation } & \multicolumn{2}{|c|}{ Lactation } \\
\hline & $\mathrm{W} / \mathrm{oFe} \mathrm{e}^{2}$ & $\mathrm{FeC}^{3}$ & W/oFe & $\mathrm{FeC}$ & $\mathbf{W} / \mathbf{o F e}$ & $\mathrm{FeC}$ \\
\hline Corn grain & 56.69 & 56.69 & 58.47 & 58.47 & 57.59 & 57.59 \\
\hline Soybean meal & 9.80 & 9.80 & 8.00 & 8.00 & 21.80 & 21.80 \\
\hline Extruded soybean meal & - & - & 9.00 & 9.00 & 11.80 & 11.80 \\
\hline Wheat bran & 30.00 & 30.00 & 21.00 & 21.00 & - & - \\
\hline Sugar & - & - & & - & 5.00 & 5.00 \\
\hline Dicalcium phosphate & 0.62 & 0.62 & 0.95 & 0.95 & 1.13 & 1.13 \\
\hline Calcitic limestone & 1.09 & 1.09 & 0.74 & 0.74 & 0.86 & 0.86 \\
\hline Common salt & 0.50 & 0.50 & 0.50 & 0.50 & 0.50 & 0.50 \\
\hline Inert $^{4}$ & 0.45 & 0.30 & 0.45 & 0.30 & 0.45 & 0.30 \\
\hline L-lysine $\mathrm{HCl}$ & 0.15 & 0.15 & 0.15 & 0.15 & 0.20 & 0.20 \\
\hline DL-methionine & 0.02 & 0.02 & 0.06 & 0.06 & 0.06 & 0.06 \\
\hline L-threonine & 0.09 & 0.09 & 0.09 & 0.09 & 0.07 & 0.07 \\
\hline Mineral and vitamin supplement ${ }^{5}$ & 0.50 & 0.50 & 0.50 & 0.50 & 0.50 & 0.50 \\
\hline Iron chelate $^{6}$ & - & 0.15 & - & 0.15 & - & 0.15 \\
\hline Total & 100.00 & 100.00 & 100.00 & 100.00 & 100.00 & 100.00 \\
\hline \multicolumn{7}{|l|}{ Calculated composition } \\
\hline Metabolizable energy (kcal/kg) & 3046.02 & 3046.02 & 3176.69 & 3176.69 & 3351.55 & 3351.55 \\
\hline Crude protein $(\%)$ & 13.79 & 13.79 & 15.01 & 15.01 & 18.95 & 18.95 \\
\hline Digestible lysine (\%) & 0.61 & 0.61 & 0.70 & 0.70 & 1.05 & 1.05 \\
\hline Digestible methionine (\%) & 0.21 & 0.21 & 0.26 & 0.26 & 0.31 & 0.31 \\
\hline Digestible tryptophan (\%) & 0.14 & 0.14 & 0.15 & 0.15 & 0.21 & 0.21 \\
\hline Digestible threonine (\%) & 0.50 & 0.50 & 0.55 & 0.55 & 0.70 & 0.70 \\
\hline Neutral detergent fiber (\%) & 20.22 & 20.22 & 18.05 & 18.05 & 12.00 & 12.00 \\
\hline Acid detergent fiber (\%) & 7.21 & 7.21 & 6.94 & 6.94 & 6.09 & 6.09 \\
\hline Calcium (\%) & 0.65 & 0.65 & 0.60 & 0.60 & 0.70 & 0.70 \\
\hline Available phosphorus (\%) & 0.27 & 0.27 & 0.35 & 0.35 & 0.35 & 0.35 \\
\hline Chlorine (\%) & 0.35 & 0.35 & 0.35 & 0.35 & 0.35 & 0.35 \\
\hline Sodium (\%) & 0.22 & 0.22 & 0.22 & 0.22 & 0.22 & 0.22 \\
\hline Iron $(\mathrm{mg} / \mathrm{kg})$ & 190.57 & 430.57 & 204.91 & 444.91 & 207.91 & 447.91 \\
\hline
\end{tabular}

${ }^{1}$ Nutritional and energetic composition of ingredients described by Rostagno et al. $2011 ;{ }^{2} \mathrm{~W} / \mathrm{oFe}$ - Diet without iron chelate supplementation; ${ }^{3} \mathrm{FeC}$ - Diet supplemented with $0.15 \%$ iron chelate source. ${ }^{4}$ Washed sand; ${ }^{5}$ Mineral and vitamin supplement: Composition per kg of product: Folic Acid: 300 mg; Pantothenic acid: 3000 mg; Biotin: 100 mg; Copper: 1990 mg; Etoxiquim: 160 mg; Iron: 19 g; Phytase: 10000024 U; Iodine: 200 mg; Manganese: 11.9 g; Niacin: 6000 mg; Selenium: 60 mg; Vitamin A: 2100000 IU; Vitamin B1: 300 mg; Vitamin B12: 5000mcg; Vitamin B2: 900mg; Vitamin B6: 500 mg; Vitamin D3: 300000 IU; Vitamin E: $8900 \mathrm{UI}$; Vitamin K3: $400 \mathrm{mg}$; Zinc: $30 \mathrm{~g} .{ }^{6}$ Yes Minerals Iron ${ }^{\circledR}: 160 \mathrm{~g} / \mathrm{kg}$ of iron amino acid chelate. 
SOLAAR software program (Thermo Scientific, Cambridge, England).

The litters were distributed into five treatments according to the treatment received by the sows: W/oFe+FeDx - sows without iron chelate supplementation and piglets receiving $2 \mathrm{~mL}$ of intramuscular iron-dextran $(100 \mathrm{mg} / \mathrm{mL}$ of irondextran); W/oFe+FeOr - sows without iron chelate supplementation and piglets receiving $5 \mathrm{~g}$ of oral iron supplementation ( $42 \mathrm{mg} / \mathrm{g}$ of oral iron chelate); $\mathrm{FeC}+\mathrm{FeDx}$ - sows supplemented with iron chelate and piglets receiving $2 \mathrm{~mL}$ intramuscular irondextran $(100 \mathrm{mg} / \mathrm{mL}$ of iron-dextran); $\mathrm{FeC}+\mathrm{FeOr}$ - sows supplemented with iron chelate and piglets receiving $5 \mathrm{~g}$ oral iron supplementation (42 $\mathrm{mg} / \mathrm{g}$ of oral iron chelate); $\mathrm{FeC}+\mathrm{W} / \mathrm{oFe}$ - sows supplemented with iron chelate and piglets without iron supplementation.

The piglets received iron supplementation on the third day of life according to the treatment group, receiving $200 \mathrm{mg}$ of intramuscular irondextran in the neck region or $200 \mathrm{mg}$ of antianemic paste deposited in the final portion of their oral cavity using a graduated tube. Both treatments were performed only once.

The oral iron supplementation used had the following chemical composition: total sugar $76.50 \mathrm{~g}$; copper chelate - $850.00 \mathrm{mg}$; dextrose $235.80 \mathrm{~g}$; Iron chelate - $42.00 \mathrm{~g}$; Lactobacilli casei - 3×10 CFU/kg; mineral matter - 6,120.00 mg; methionine - 2,900.00 mg; crude protein - 900.00 $\mathrm{mg}$; Saccharomyces cerevisiae $-4.5 \times 10^{10} \mathrm{CFU} / \mathrm{g}$; Vitamin C - 2,000.00 mg.

The piglets were weighed and weaned at 21 days of age, obtaining the mean weaning weight, litter weight at weaning and number of piglets weaned per sow. The daily weight gain per piglet was then calculated based on the weight at 21 days and initial weight. The piglets did not receive any supplemental solid diet throughout the experimental period. Acquisition of minerals through the ingestion of sow feces was also not observed.

The data were submitted to analysis of variance and the normality of errors was tested by the Cramer-von Mises test (Everitt 1998). The performance data of the sows were compared by the F-test at $5 \%$ probability. For iron concentration in sow milk, asplit-plot design was performed considering the experimental diets as $(\mathrm{W} / \mathrm{oFe}$, $\mathrm{FeC})$ and days postpartum $(1,7,14$ and 21) as subplots, and means were compared by Tukey test at $5 \%$ probability. Performance data of piglets and litters were submitted to analysis of variance and compared by Tukey test at $5 \%$ probability.

\section{RESULTS AND DISCUSSION}

No influence of iron chelate supplementation $(\mathrm{P}>0.05)$ on the reproductive parameters of sows was verified (Table II). The lack of significant difference could be related to the high control of placental iron transfer from mother to fetus, which is dependent on uteroferrin and is responsible for transporting this mineral (Lipiński et al. 2012).

The efficiency of maternal-fetal iron transfer is directly related to the iron status of the sow, especially in periods of high demand, such as gestation and lactation phases. Thus, it is possible that the sows have an adequate body mineral composition, which may result in a decrease in the mineral absorptive iron rate, and thus not increasing its transfer to the fetus (Papadopoulos et al. 2009). After the iron is absorbed by the maternal intestine is carried up to the liver. In non-pregnant animals, about $40 \%$ of the iron is incorporated into the liver in the first passage through the portal circulation, however, it is not known exactly how this regulation occurs during pregnancy, but the liver plays an important role in iron homeostasis. Little is known how this mineral is transferred to the fetus. During pregnancy the concentrations decrease greatly, so that this process can not occur which is probably 
TABLE II

Reproductive parameters of sows fed diets with or without iron chelate supplementation at gestation phase.

\begin{tabular}{|c|c|c|c|c|}
\hline \multirow{2}{*}{ Productive Parameters } & \multicolumn{2}{|c|}{ Treatments } & \multirow{2}{*}{ CV(\%) } & \multirow{2}{*}{ P value } \\
\hline & W/oFe & FeC & & \\
\hline Number of sows & 20 & 30 & - & - \\
\hline Total number of piglets born & 14.45 & 14.83 & 14.66 & 0.1551 \\
\hline Piglets born alive & 13.40 & 13.47 & 11.24 & 0.7523 \\
\hline Stillborn piglets & 1.05 & 1.37 & 26.85 & 0.0578 \\
\hline Piglet weight at birth & 1.39 & 1.35 & 14.80 & 0.5315 \\
\hline Litter weight at birth & 18.55 & 18.19 & 19.44 & 0.8121 \\
\hline
\end{tabular}

CV - Coefficient of variation; P - probability; W/oFe - Without iron supplementation; FeC - With 0.15\% iron chelate supplementation.

regulated by signals emitted from the developing fetus (Gambling et al. 2011).

The present study collaborates with other authors also did not observe a difference for reproductive parameters of sows supplemented with organic trace minerals (including iron) in relation to inorganic trace minerals supplementation, emphasizing the complexity of the reproductive process and that sows in parity order above 5 do not present mineral deficiency (Wang et al. 2013).

On the other hand, iron reserves in sows are able to increase the deposition on the fetal and mammary tissues by increasing the bioavailability of mineral from dietary sources, including organic trace minerals which chelation characteristics protect against physico-chemical factors and negative interactions with dietary ingredients such as complexation with phytic acid, which may render the iron unavailable for absorption (West and Oates 2008, Feng et al. 2009, Gowanlock et al. 2015).

Contrary to the results found in the present study, Bertechini et al. (2012) found that supplementation with organic minerals containing $80 \mathrm{mg}$ of iron/ $\mathrm{kg}$ of feed for sows during gestation and lactation positively influenced piglet weight at birth and weaning, weight gain and the number of live birth piglets compared to sows supplemented with inorganic minerals at supplementation levels of 1000 and $2000 \mathrm{mg} / \mathrm{ton}$.
According to the NRC (1998), a concentration of $80 \mathrm{mg}$ of iron $/ \mathrm{kg}$ of feed is recommended for pregnant sows; however, it is common to observe that higher levels have been used on farms (120 $\mathrm{mg} / \mathrm{kg}$ ) to guarantee mineral supply during the final third of gestation and during lactation (Mahan et al. 2009). Thus, the levels used in this study (190 $\mathrm{mg} / \mathrm{kg}$ ) seem to meet the requirements of the sows for all studied phases, regardless of organic iron supplementation.

No influence $(\mathrm{P}>0.05)$ of the treatments were observed on the productive parameters of sows during the lactation phase (Table III). Despite the dietary iron supplementation, it probably did not contribute to an improvement in the absorption and incorporation of this mineral in both maternal and fetal tissues, demonstrating similar performances in both treatments.

The Fe concentration in the feces of sows was affected by treatments (Table IV), however, without influence $(\mathrm{P}>0.05)$ on $\mathrm{Cu}$ and $\mathrm{Zn}$ concentrations. Although the results show greater fecal excretion of iron from the supplementation of this mineral in the organic form, it cannot be affirmed that it has been less efficient in its availability and or incorporation by the animals.

In contrast, Feng et al. (2009) and Zhang et al. (2016) found lower Fe excretions in pigs and chickens, respectively, with dietary ironGly/glycine-iron up to $120 \mathrm{mg} / \mathrm{kg}$ compared to the inorganic source $\left(\mathrm{FeSO}_{4}\right)$. These results 
TABLE III

Productive parameters of sows fed diets with or without iron chelate supplementation at lactation phase.

\begin{tabular}{|c|c|c|c|c|}
\hline \multirow{2}{*}{ Productive parameters } & \multicolumn{2}{|c|}{ Treatments } & \multirow{2}{*}{ CV $(\%)$} & \multirow{2}{*}{ P value } \\
\hline & W/oFe & $\mathrm{FeC}$ & & \\
\hline Average daily feed intake (kg) & 5.65 & 5.69 & 5.25 & 0.5141 \\
\hline Weaned piglets & 11.65 & 11.70 & 11.10 & 0.9985 \\
\hline Litter weight at weaning $(\mathrm{kg})$ & 67.78 & 65.92 & 11.26 & 0.3954 \\
\hline Average daily consumption/weaned piglet $(\mathrm{kg})$ & 0.488 & 0.486 & 11.88 & 0.9108 \\
\hline Feed conversion/weaned piglet & 1.77 & 1.81 & 13.05 & 0.6365 \\
\hline Percentage of weaned piglets $(\%)$ & 88.11 & 87.96 & 13.43 & 0.9642 \\
\hline
\end{tabular}

CV - Coefficient of variation; P - probability; W/oFe - Without iron supplementation; FeC - With $0.15 \%$ iron chelate supplementation.

TABLE IV

Concentration of iron, zinc and copper $(\mathrm{mg} / \mathbf{1 0 0 g})$ in the feces of pregnant sows fed diets with or without iron chelate supplementation.

\begin{tabular}{cccccc}
\hline \multirow{2}{*}{$\begin{array}{c}\text { Concentration of minerals } \\
\mathbf{m g} / \mathbf{1 0 0 g} \text { feces }\end{array}$} & \multicolumn{2}{c}{ Treatments } & \multirow{2}{*}{ CV (\%) } & \multirow{2}{*}{ P value } \\
\cline { 2 - 4 } Iron & $112.13 \mathrm{~b}$ & $157.32 \mathrm{a}$ & 17.92 & 0.0013 \\
Zinc & 274.03 & 289.51 & 11.59 & 0.3458 \\
Copper & 100.52 & 102.21 & 8.51 & 0.6751 \\
\hline
\end{tabular}

$\mathrm{CV}$ - Coefficient of variation; P - probability; W/oFe - Without iron supplementation; FeC - With $0.15 \%$ iron chelate supplementation. Means followed by different letters differ from one another by the F-test ( $5 \%$ of probability).

demonstrate better availability of this mineral as organic source using same level of supplementation as the inorganic form.

A higher excretion of $\mathrm{Fe}$ in sows that received higher levels of organic mineral is in agreement with other studies that indicate greater excretions of the mineral with increasing level in diet, regardless the mineral source. However, many factors may interfere in the bioavailability of Fe and other minerals, such as chemical characteristics of the sources, supplemented levels, the status of Fe in the body, indices of evaluation and reference standards (Ma et al. 2012, Liu et al. 2014).

The values of iron concentration in colostrum and milk of sows fed diet with or without iron chelate supplementation were not affected $(\mathrm{P}>0.05)$; however, a higher concentration of iron $(\mathrm{P}<0.05)$ was observed in colostrum in relation to milk from the sows at 7,14 and 21 days (Table V).

The higher concentration of iron observed in colostrum is due to a greater transfer of nutrients through the epithelial cells of the secretory ducts during the first hours of lactation, gradually decreasing until weaning (Hanusovsky et al. 2014).

The mineral composition of colostrum can be influenced by factors that affect the mineral needs of pregnant sows, mineral supplementation in diet and mineral status, as demonstrated by Peters et al. (2010). These same authors observed that macro and trace mineral concentrations were higher in colostrum compared to milk when pregnant sows were supplemented with organic and inorganic minerals.

The synthesis of colostrum is largely initiated prior to parturition, therefore its composition may be influenced by other mineral requirements in sow reproduction, especially during the final phase of fetal growth during pregnancy (Papadopoulos et al. 2009, Peters et al. 2010).

The concentration of iron in colostrum and milk can be increased according to the offered diet, however, this modulation occurs on a low scale 
TABLE V

Iron concentration $(\mathrm{mg} / \mathrm{L})$ in the milk of sows fed diets with or without iron chelate supplementation at day 1 (colostrum), 7, 14 and 21 days of lactation.

\begin{tabular}{ccccccccccc}
\hline & \multicolumn{3}{c}{ Treatments (T) } & \multicolumn{3}{c}{ Days (D) } & \multicolumn{3}{c}{ P value } \\
\hline & $\mathrm{W} / \mathrm{oFe}$ & $\mathrm{FeC}$ & 1 & 7 & 14 & 21 & $\mathrm{~T}$ & $\mathrm{D}$ & $\mathrm{T} \times \mathrm{D}$ \\
\cline { 2 - 11 } $\mathrm{Fe}(\mathrm{mg} / \mathrm{L})$ & 1.85 & 2.00 & $2.521 \mathrm{a}$ & $1.658 \mathrm{~b}$ & $1.843 \mathrm{~b}$ & $1.691 \mathrm{~b}$ & 0.1100 & 0.0001 & 0.0813 \\
\hline
\end{tabular}

1 - Colostrum; W/oFe - without iron supplementation; FeC - With $0.15 \%$ iron chelate supplementation. Means followed by different letters differ from one another by the Tukey test ( $5 \%$ of probability).

TABLE VI

Performance of piglets as a function of iron chelate supplementation of sows and the type of iron supplementation at farrowing.

\begin{tabular}{ccccccccc}
\hline \multirow{2}{*}{ Parameters } & \multicolumn{9}{c}{ Treatments } & & \\
\cline { 2 - 6 } & $\begin{array}{c}\text { W/oFe+ } \\
\text { FeDX }\end{array}$ & $\begin{array}{c}\text { W/oFe+ } \\
\text { FeOr }\end{array}$ & $\begin{array}{c}\text { FeC+ } \\
\text { FeDx }\end{array}$ & $\begin{array}{c}\text { FeC+ } \\
\text { FeOr }\end{array}$ & FeC+W/oFe & CV (\%) & P value \\
Weaned piglets & 11.60 & 11.80 & 11.50 & 11.90 & 11.5 & 11.40 & 0.9662 \\
Weaning weight $(\mathrm{kg})$ & $6.06 \mathrm{a}$ & $5.57 \mathrm{ab}$ & $6.14 \mathrm{a}$ & $5.61 \mathrm{ab}$ & $5.30 \mathrm{~b}$ & 10.04 & 0.0102 \\
Average daily gain $(\mathrm{kg})$ & $0.222 \mathrm{ab}$ & $0.199 \mathrm{ab}$ & $0.226 \mathrm{a}$ & $0.201 \mathrm{ab}$ & $0.191 \mathrm{~b}$ & 12.72 & 0.0169 \\
\hline
\end{tabular}

CV - Coefficient of variation; P - probability; Means followed by different letters differ from one another by the Tukey test (5\% of probability). W/oFe+FeDx - sows without iron chelate supplementation and piglets receiving of intramuscular iron-dextran; $\mathrm{W} / \mathrm{oFe}+\mathrm{FeOr}-$ sows without iron chelate supplementation and piglets receiving oral iron supplementation; FeC $+\mathrm{FeDx}-\mathrm{sows}$ supplemented with iron chelate and piglets receiving intramuscular iron-dextran; FeC+FeOr - sows supplemented with iron chelate and piglets receiving oral iron supplementation; $\mathrm{FeC}+\mathrm{W} / \mathrm{oFe}$ - sows supplemented with iron chelate and piglets without iron supplementation.

which does not meet the daily requirements of the piglets, thus allowing the onset of iron deficiency anemia (Hansen et al. 2010).

Although no differences were observed between the treatments for piglet weight and litter weight at birth from sows supplemented or not supplemented with iron chelate, it was observed that iron-dextran supplementation resulted in heavier piglets at weaning $(\mathrm{P}<0.05)$, when compared to piglets that did not receive iron supplementation, regardless of dietary iron supplementation of sows (Table VI), although not differing to those received oral iron supplementation.

The accelerated growth shown by the piglets after birth increases the demand of iron for tissue development, leading to a decrease in erythrocyte levels in the first two days of life, reaching levels close to the minimum limit $(80 \mathrm{mg})$ when iron deficiency anemia is observed (Lipiński et al. 2010).
The results of this study are similar to those found by Peters and Mahan (2008a), in which piglets receiving intramuscular iron had higher average daily gain compared to those not injected.

Several studies have demonstrated the superiority of using injectable iron in the treatment of anemia on blood parameters of hemoglobin and hematocrit, and consequently positive effects on the growth and performance of piglets (Peters and Mahan 2008b, Lipiński et al. 2010).

The lowest ADG and weaning weight of $\mathrm{FeC}+\mathrm{W} / \mathrm{oFe}$ piglets are mainly due to low ingestion of Fe and depletion of body reserves, leading them to present anemia (paleness).

Similar results were also observed by Wang et al. (2013), in which supplementation of pregnant and lactating sows with organic iron was not able to prevent anemia in piglets that did not receive iron supplementation, due to the iron transfer barrier 
in the placenta and breast tissue, as well as to the rapid increase of piglet iron requirements during the lactation phase.

Given the above, the results obtained in this study show that dietary supplementation of iron chelate does not influence the reproductive parameters of sow, increasing iron excretion in the feces. However, it is also verified that the piglets need to be supplemented with iron, regardless of the source, so that they can obtain satisfactory performance.

\section{CONCLUSION}

Dietary iron chelate supplementation does not improve the productive parameters of sows and increases iron excretion in feces, thus requiring iron supplementation for the piglets after birth.

\section{ACKNOWLEDGMENTS}

The authors are thankful to the Coordenação de Aperfeiçoamento de Pessoal de Nível Superior (CAPES) and Yes Minerals organization for supporting this research.

\section{AUTHOR CONTRIBUTIONS}

Leonardo Augusto Fonseca Pascoal, Pedro Henrique Watanabe and Terezinha Domiciano Dantas Martins were responsible for Project management, while Carine Araújo Barros and José Evangelista Santos Ribeiro assisted in laboratory assessment of biological samples. Carine Araújo Barros and Tiago Silva Andrade were involved in data collection and laboratory work. Carine Araújo Barros, Leonardo Augusto Fonseca Pascoal, Pedro Henrique Watanabe and Terezinha Domiciano Dantas Martins were responsible for writing revisions.

\section{REFERENCES}

BERTECHINI AG, FASSANI EJ, BRITO JAG AND BARRIOS PR. 2012. Effects of dietary mineral bioplex in pregnant and lactating sow diets on piglet performance and physiological characteristics. R Bras Zootec 41: 624-629.
EVERITT BS. 1998. The Cambridge Dictionary of Statistics, Cambridge: Cambridge University Press, 360 p.

FENG J, MA WQ, XU ZR, HE JX, WANG YZ AND LIU JX. 2009. The effect of iron glycine chelate on tissue mineral levels, fecal mineral concentration, and liver antioxidant enzyme activity in weanling pigs. Anim Feed Sci Tec 150: 106-113.

GAMBLING L, LANG C AND MCARDLE HJ. 2011. Fetal regulation of iron transport during pregnancy. Am J Clin Nutr 94: 1903-1907.

GOWANLOCK DW, MAHAN DC, JOLLIFF JS AND HILL GM. 2015. Evaluating the influence of National Research council levels of copper, iron, manganese, and zinc using organic (Bioplex) mineral on resulting tissue mineral concentrations, metallothionein, and liver antioxidant enzymes in grower-finisher swine diets. J Anim Sci 93: 1149-1156.

HANSEN SL, TRAKOOLJUL N, SPEARS JW AND HSIAOCHING L. 2010. Age and dietary iron affect expression of genes involved in iron acquisition and homeostasis in young pigs. J Nutr 140: 271-277.

HANUSOVSKY O, BIRO D, GALIK B, ROLINEC M, SIMKO M, JURACEK M AND RUSINOVA M. 2014. Changes in the average concentration of minerals in the colostrum os sows during the first 48 hours after parturition. Res Pig Breed 8: 32-35.

HUANG YL, LU L, XIE JJ, LI SF, LI XL, LIU SB, ZHANG LY, XI L AND LUO XG. 2009. Relative bioavailabilities of organic zinc sources with diferente chelation strengths for broilers fed a conventional corn-soybean meal diet. J Anim Sci 87: 2038-2041.

JOLLIFF JS AND MAHAN DC. 2011. Effect of injected and dietary iron in young pigs on blood hematology and postnatal pig growth performance. J Anim Sci 89: 40684080.

KOWALCZYK P, DZIAMAN T, THIBAUDEAU O, GRALAK MA AND SMUDA E. 2010. Benefits and risks of iron supplementation in anemic neonatal pigs. Gastro Hep Panc Patho 177: 1233-1243.

LIPIŃSKI P, STARZYŃSKI RR, CANONNE-HERGAUX F, TUDEK B, OLIŃSKI R, KOWALCZYK P, DZIAMAN T, THIBAUDEAU O, GRALAK MA AND SMUDA E. 2010. Benefits and risks of iron supplementation in anemic neonatal pigs. Am J Pathol 177: 1233-1243.

LIPIŃSKI P, STYŚ A AND STARZYŃSKI RR. 2012. Molecular insights into the regulation of iron metabolism during the prenatal and early postnatal periods. Cell Mol Life Sci 70: 23-38.

LIU Y, MA YL, ZHAO JM, VAZQUEZ-ANÓN M AND STEIN HH. 2014. Digestibility and retention of zinc, copper, manganese, iron, calcium, and phosphorus in pigs fed diets containing inorganic or organic minerals. J Anim Sci 92: 3407-3415. 
MA WQ, SUN H, ZHOU Y, WU J AND FENG J. 2012. Effects of iron glycine chelate on growth, tissue mineral concentrations, fecal mineral excretion, and liver antioxidant enzyme activities in broilers. Biol Trace Elem Res 149: 204-211.

MAHAN DC, WATTS MR AND ST-PIERRE N. 2009. Macro and micromineral composition of fetal pigs and their accretion rates during fetal development. J Anim Sci 87: 2823-2832.

NRC- NATIONAL RESEARCH COUNCIL. 1998. Nutrient Requirement of Swine, Academic press, $185 \mathrm{p}$

PAPADOPOULOS GA, MAES DGD AND JANSSENS GPJ. 2009. Mineral accretion in nursing piglets in relation to sow performance and mineral source. Vet Med 54: 41-46.

PETERS JC AND MAHAN DC. 2008a. Effects of dietary organic and inorganic trace mineral levels on sow reproductive performances and daily mineral intakes over six parities. J Anim Sci 86: 2247-2260.

PETERS JC AND MAHAN DC. 2008b. Effects of neonatal iron status, iron injections at birth, and weaning in young pigs from sows fed either organic or inorganic trace minerals. J Anim Sci 86: 2261-2269.
PETERS JC, MAHAN DC, WISEMAN TG AND FASTINGER ND. 2010. Effect of dietary organic and inorganic micromineral source and level on sow body, liver, colostrum, mature milk, and progeny mineral compositions over six parities. J Anim Sci 88: 626-637.

ROSTAGNO HS, ALBINO LFT, DONZELE JL, GOMES PC, OLIVEIRA RF, LOPES DC, FERREIRA AS, BARRETO SLT AND EUCLIDES RF. 2011. Tabelas brasileiras para aves e suínos: composição de alimentos e exigências nutricionais de aves e suínos. $3^{\text {a }}$ edição, Viçosa, MG: UFV, $252 \mathrm{p}$.

WANG J, LI D, CHE L, LIN Y, FANG Z, XU S AND WU D. 2013. Influence of organic iron complex on sow reproductive performance and iron status of nursing pigs. Livest Sci 160: 89-96.

WEST AR AND OATES PS. 2008. Mechanisms of heme iron absorption: Current questions and controversies. World J Gastroenterol 14: 4101-4110.

ZHANG LY, LU L, ZHANG LY AND LUO XG. 2016. The chemical characteristics of organic iron sources and their relative bioavailabilities for broilers fed a conventional corn-soybean meal diet. J Anim Sci 94: 2378-2396. 